\title{
Turkish EFL Students' Perceptions of ELF and its Pedagogical Implications*
}

Fikri GEÇKINLI $\mathbf{I}^{* *}$

\author{
Cevdet YILMAZ $^{* * *}$
}

\begin{abstract}
English has established itself as a lingua franca for people from a variety of linguistic and cultural origins in today's more globalized world. As a result, English's current position is likely to have an effect on both EFL students' perceptions of the language and its pedagogy. The purpose of this study was to elicit students' perspectives of English as a lingua franca (ELF) - defined as a common medium of communication for persons with varied linguistic and cultural origins and its instructional implications. To do this, data were gathered through the use of a five-point Likert-scale questionnaire devised by the researcher. The survey sampled 570 Turkish EFL students enrolled in a foundation university's English preparatory program in the Istanbul province. The findings indicated that EFL students were unsure not just about English's standing as a lingua franca, but also about its instructional consequences. In other words, they were cautious to endorse such a novel concept. In light of these significant findings, implications for language teaching/learning scenarios were discussed, as well as ideas for additional research.
\end{abstract}

Keywords: English as a lingua franca (ELF), Pedagogical implications, English language teaching (ELT), English as a Foreign Language (EFL) Students.

\footnotetext{
* Ethics approval was obtained from the Ethics Committee of İstanbul Sabahattin Zaim University with the decision dated 28.01.2021 numbered 2021/01.

${ }^{* *}$ Orcid ID: https://orcid.org/0000-0002-3572-5939, Lect. İstanbul Sabahattin Zaim University, Turkey, fgeckinli@gmail.com

${ }_{* * *}$ Orcid ID: https://orcid.org/0000-0003-4713-6565, Prof. Dr., Çanakkale Onsekiz Mart University, Turkey, cyilmaz@comu.edu.tr
} 


\section{INTRODUCTION}

As English has grown in popularity throughout the world, research into its use as a common medium of communication has risen in tandem. Similarly, the research community has begun to focus on the language practice characteristics of speakers who use English as a lingua franca (ELF) (e.g., Cogo \& Dewey, 2012), which is defined as the adoption of English as a common medium of communication by speakers from various linguistic and cultural backgrounds (Jenkins, 2006). Additionally, several corpora have been created with the intention of examining the discourse characteristics of ELF speakers (i.e., VOICE, ELFA, and ACE). As a result, some conclusions have been drawn about what these speakers know about language, what they are capable of doing with English, how they incorporate other languages they are familiar with into communication, and the strategies they employ on the spot to communicate with their interlocutors (Jenkins, 2015; Ferguson, 2013; Seidlhofer, 2011).

The initial ELF research endeavored to explain this concept from a variety of perspectives (Jenkins, 2015; Seidlhofer, 2004), recognizing the fact that ELF has pedagogical implications for the English classroom (Jenkins, 2012). The most striking of these conclusions is that the ELF perspective instills confidence in non-native English speakers and provides them with an opportunity to develop into successful communicators (Bayyurt \& Sifakis, 2015). Additionally, ELF research challenges stakeholders in the language education process to rethink their conventional views and practices regarding ELT pedagogy (Sifakis 2009). As a result, the research findings may enable them to make some innovations based on the findings of the ELF research.

Nonetheless, integrating an ELF perspective into the established traditional ELT industry may not be as straightforward. One of these difficulties may stem from the fact that the concept of ELF is already comprised of a number of complex attributes. Another possibility is that the current native language-oriented ELT industry would not readily allow for such a change. In order to facilitate this adaptation, Sifakis (2019) developed an ELF awareness perspective, which includes (1) language and language use awareness, (2) educational practices awareness, and (3) learning awareness. The third component, in particular, is concerned with raising EFL learners' awareness of ELF, whose attitudes are critical because they are essential stakeholders in ELT. However, we do not know much about how EFL students will react to the suggestions made by the ELF perspective. As a result, it is necessary to investigate their perceptions of ELF and its pedagogical implications as reported in this article.

\section{Literature Review}

Kachru's (1985) three concentric circles conceptualized the global use of English. The inner circle countries, in particular, set standards for the others, and English is widely spoken as a first language in these countries (e.g., UK, USA). The countries of the outer circle are those that are developing their own standards, and English serves as a second language in these multilingual settings (e.g., Malaysia, Singapore, India, Ghana, and Kenya). Finally, expanding circle countries are those that are linguistically dependent on 
native English-speaking countries, with English being used as a foreign language in these countries (e.g., Turkey, China, Japan, and Greece). And, even today, Kahcru's division of world Englishes is regarded as a critical stepping stone.

However, some scholars (Yoneoka, 2002; Jenkins, 2003; Bruthiaux, 2003; Park \& Wee, 2009; Pung, 2009) who raised concerns about the divisions paved the way for the concept of ELF to be developed further. A weakness of the model according to Canagarajah (2006) is the fluidity of these circles as a result of global migration and globalization in many aspects of life, which he believes is due to globalization in many aspects of life. Because of the large number of English speakers who have moved from one country to another, it is difficult to determine which countries are in the inner, outer, or expanding circles. Furthermore, the free movement of people, goods, and ideas across borders has resulted in the emergence of hybrid languages, communities, and cultures. English is therefore pluralized, and we cannot treat English as a homogeneous language characterized by constant norms and a consistent grammatical structure (Canagarajah, 2006). In terms of continuity, Canagarajah (2006) argues that it is also difficult to talk about general or universal proficiency because proficiency is context and time dependent, and can only be addressed meaningfully in a specific context and within a community of practice (Canagarajah 2006).

Furthermore, the traditional conceptualization of English has changed as a result of the language's widespread use across international borders. According to Brumfit (2001), speakers of English as a mother tongue have numerically lost the lead as well as ownership of this language, which refers to the ability to adapt and change a particular language. As a result, strict adherence to native speaker conventions is no longer required. Accordingly, gaining a better understanding of the new nature of language and its use as a foundation for pedagogical practices, not only from the viewpoint of teachers, but also from the perspectives of students, would provide us with greater insight into the changing circumstances.

Several studies have been conducted in this regard, both in Turkey and abroad, to ascertain EFL teachers' and students' attitudes toward ELF. Timmis (2002), for example, sought to elicit responses from EFL teachers and students from various countries to native speaker norms for pronunciation and grammar. While the majority of students preferred native speaker pronunciation, the majority of teachers favored an understandable non-native accent. However, both groups demonstrated a strong tendency toward native-like competence in grammar.

Ranta (2010) also investigated non-native English teachers' and students' perceptions of the global role of English in Finland's upper secondary schools. The findings indicated that, despite instructors and students' awareness of English's significance as a lingua franca, educational authorities and test planners continued to support norm-based school English. Pan and Block (2011), on the other hand, evaluated the language beliefs of university faculty and students in Beijing. The findings indicated that participants 
viewed English as a global language and a sign of social prestige, as well as a tool for China's growth.

Wang (2013) used questionnaires and in-depth interviews to investigate the perceptions of professionals and university students in China regarding non-conformity to native English norms. The questionnaire results indicated that participants had a slight positive tendency toward deviation from standard English varieties. They did, however, attempt to strike a balance between conformity and non-conformity to native English norms during the interviews. According to the study, participants preferred native English because it was perceived as the essence of the language and was socially preferred. They did, however, support deviation from native English in order to communicate more effectively and project their cultural identities.

In terms of the studies conducted in the Turkish context, they were primarily concerned with EFL teachers' perceptions of ELF, with less attention paid to EFL students' perceptions (Soruç, 2015; İnceçay \& Akyel, 2014; Coşkun, 2011; Bayyurt, 2008; Soruç, 2020; Soruç \& Griffiths, 2021; Zabitgil Gülseren \& Sarıca, 2020).

Using the ELF framework, Coşkun (2011) conducted a study in which he investigated pre-service English language teachers' perceptions of teaching pronunciation. The findings revealed that prospective EFL teachers believed that native-speaker English, and thus native speaker pronunciation, was the most appropriate model for English language teaching.

Likewise, İnceçay and Akyel (2014) examined Turkish EFL teachers' perceptions of ELF and its potential role in language teacher education. At the time of the study, all participants were employed in English preparatory schools affiliated with Istanbul's two English-medium universities. Except for oral language use, the research findings indicated that participants were opposed to the use of ELF in their classrooms. Additionally, they advocated for integrating diverse cultures into the classroom and incorporating ELF into teacher education programs.

Soruç (2015) investigated whether non-native English teachers from five expanding countries (Turkey, Italy, Egypt, Germany, and China) would use incorrect ELF features in Seidlhofer's (2004) list. The findings indicated that these teachers place a high premium on native English norms. Similarly, another study found that Turkish EFL teachers valued not only accurate and appropriate English use, but also expected their students to achieve native-like English proficiency (Soruç, 2020). However, once EFL teachers become more aware of ELF, they are more likely to adopt an ELF-aligned perspective (Soruç \& Griffiths, 2021; Bayyurt, 2008). On the other hand, when Griffiths and Soruç (2019) investigated the students' perceptions of ELF in Turkey (an expanding circle country) and in New Zealand (an inner circle one), they found that the EFL students in Turkey opted for native speaker way of communciation, those in New Zealand wanted to use English as a lingua franca to communicate with other speakers from various linguabackgrounds. 
Zabitgil Gülseren and Sarıca (2020) conducted a study with EFL teachers and students from public secondary schools to determine their inclination for using mother tongue in the teaching and learning of English. While the study's students did not prefer native English teachers in ELT classrooms, the study's English teachers surprisingly preferred native English teachers, particularly when it came to teaching specific language skills such as speaking. This demonstrates that, in contrast to their students, non-native English teachers are adamant about preserving native English ideology, even at the expense of the respect they deserve as a non-native English teacher.

By and large, these studies demonstrate that EFL teachers and students appreciate the value of English as a lingua franca; nonetheless, present ELT methods continue to place a premium on obtaining native speaker proficiency. As a result, in order to maintain language instruction current, it is well worth examining EFL students' perspectives of the English language's ever-changing conditions within the field of English studies. Therefore, it becomes critical to investigate the views of English preparatory school students on this subject.

With the purpose of analyzing EFL students' opinions of ELF and its pedagogical implications from the perspective of survey respondents at a university English preparatory program, this study intended to address the following questions:

1. What are Turkish EFL students' perceptions toward the concept of ELF?

2. How do Turkish EFL students perceive ELF as a concept in light of the following factors: English varieties, ELF features, and English learning objectives?

3. What are Turkish EFL students' perceptions toward the pedagogical implications of ELF?

4. How do Turkish EFL students perceive ELF as a concept in light of the following factors: English teachers, target language culture, global cultures, and English exams?

\section{METHOD}

\section{Research Design}

The study was descriptive in nature. Babbie (2010) defines descriptive design as explaining circumstances. What, where, when, and how questions are usually answered through descriptive designs in social science studies. Furthermore, due to the growing push for internationalization in higher education, the study was conducted at a foundation university with a sizable international student population. Accordingly, the necessary quantitative, numerical, data were collected from the participating students, as this technique allows for the collection of ideas from a large population size (Pinsonneault \& Kraemer, 1993).

\section{Setting and Participant}

Ethics approval was obtained from the Ethics Committee of İstanbul Sabahattin Zaim University with the decision dated 28.01.2021 numbered 2021/01. When selecting the 
participants $(\mathrm{N}=570)$ for this study, convenience sampling was used due to the researcher's ease of access to the study's target population (Dörnyei, 2007; MacKay \& Gass, 2005). The study took place in an English preparatory program at a foundation university with an English medium in the province of Istanbul. Due to the fact that English was the medium of instruction at this university, students were required to demonstrate a certain level of proficiency in the language prior to beginning their departments. They were required to demonstrate their proficiency by earning the required minimum passing scores on the following exams: 70 on the universityadministered English Proficiency Exam, 68 on the TOEFL (IBT), 520 on the TOEFL (PBT), and 5.5 on the IELTS. If students were unable to submit any of these scores to the university, as was frequently the case, they were expected to enroll in an English preparatory program and achieve the required level of competence. This program offered instruction at four levels in accordance with the CEFR's modular system (A1, A2, B1, and B2). After completing B2, students complete the program. Among the $570 \mathrm{EFL}$ students, 255 were male and 315 were female. According to the CEFR module distribution, 126 students were in A1, 222 students were in A2, 112 students were in $B 1$, and 110 students were in B2.

\section{Data Collection Instrument}

This study utilized a 5-point Likert scale questionnaire developed by the researcher based on pertinent literature (Deniz, Özkan \& Bayyurt, 2016; Jenkins, 2015; Soruç, 2015; İnceçay \& Akyel, 2014; Cogo \& Dewey, 2012; Coşkun, 2011; Seidlhofer, 2011; Ton \& Pham, 2010) and previously published in his doctoral dissertation (Geçkinli, 2020). Following piloting and factor analysis, the number of questions was reduced from 38 to 26 due to some questions' low factor loading (less than.40) (Peterson, 2000). The questionnaire's reliability was determined by Cronbach's alpha, which was .71 after factoring (George \& Mallery, 2003). The first section of the questionnaire elicited information about the respondent's demographic characteristics, including their gender and current module affiliation (i.e., A1, A2, B1, B2). The second section, which included 13 questions, examined participants' perceptions of ELF as a concept in relation to three factors: English varieties, ELF features, and English learning objectives. Additionally, the third section, which included 13 additional items, examined their attitudes toward the pedagogical implications of ELF in light of the following factors: English teachers, target language culture, global cultures, and English examinations

\section{Data Collection Procedure and Data Analysis}

All permissions were obtained prior to data collection from the university administration and the head of the English preparatory program. The researcher coordinated with the program's head to conduct the questionnaire at an appropriate time. The questionnaire and consent forms were then distributed to students, who completed and returned the surveys within about 30 minutes. Additionally, they were encouraged to respond to all questions with their most sincere thoughts. Once all of these procedures were completed, the data were transferred to a computer for analysis. 
SPSS 25 was used to generate various types of descriptive statistics about EFL students' perceptions of ELF and its pedagogical implications. To begin, percentages and frequencies were calculated using demographic data on students, which revealed their genders and CEFR modules. Following that, students' responses were analyzed cumulatively using mean values and standard deviations in order to elicit commonalities in their perspectives on ELF and its pedagogical implications (Levin \& Wadmany, 2006). To be more precise, mean values were calculated using the following scales: $1.00-1.80=$ strongly disagree, $1.81-2.60=$ disagree, $2.61-3.40=$ neutral, $3.41-4.20=$ agree and 4.21-5.00 = strongly agree (Hemmati \& Mojarrad, 2016).

\section{FINDINGS}

The first research question sought to elicit information about EFL students' overall attitudes toward the ELF construct. To this end, descriptive statistics were applied to the quantitative data in order to generate a response to the pertinent inquiry. As such, Table 1 contains the fundamental indicators from this perspective.

Table 1

Overall Perceptions of EFL students towards the Concept of ELF

\begin{tabular}{lccccccc}
\hline & & Range Value & N & Mean & SD & Min. & Max. \\
\hline Strongly Disagree & $(1)$ & $1.00-1.80$ & & & & & \\
Disagree & $(2)$ & $1.81-2.60$ & & & & & \\
Neutral & $(3)$ & $2.61-3.40$ & 570 & 3.24 & 0.46 & 2.08 & 4.69 \\
Agree & $(4)$ & $3.41-4.20$ & & & & & \\
Strongly Agree & $(5)$ & $4.21-5.00$ & & & & & \\
\hline
\end{tabular}

As illustrated in Table 1, the data indicate that the lowest score for students' perceptions of ELF is 2.08, while the highest score is 4.69. Thus, the students' overall perceptions are in the neutral range, with a mean value of 3.24. Additionally, the percentage distributions of these results are as follows, according to the Likert scale ranges: 6.45 percent strongly disagree, 13.61 percent strongly disagree, 20.63 percent strongly disagree, 31.82 percent strongly agree, and 27.46 percent strongly agree. The findings indicate that students' general attitudes toward the concept of ELF are neutral. Additionally, the standard deviation (0.46) is within the acceptable range, indicating that the group is homogeneous and that more than half of the students share similar perceptions. In other words, the students in the group demonstrated an unbiased attitude toward ELF without adopting a strongly antagonistic stance. 
The second research question sought to expand on the first by examining EFL students' perceptions toward ELF in relation to three sub-dimensions: English varieties, ELF features, and English learning objectives. Table 2 summarizes the overall perceptions of EFL students in this regard.

Table 2

Factors about the Perceptions of EFL Students towards the Concept of ELF

\begin{tabular}{llll}
\hline Factors & $\mathrm{N}$ & Mean & SD \\
\hline English Varieties & 570 & 2.94 & 0.68 \\
ELF Features & 570 & 3.90 & 0.71 \\
English Learning & 570 & 2.72 & 0.74 \\
Objectives & & & \\
\hline
\end{tabular}

The ELF questionnaire's first factor examined EFL learners' perceptions of English varieties. The findings indicate that EFL students have a tendency to be ambivalent about whether American or British English is the superior variety of the language. Additionally, they are indecisive about their familiarity with non-native English varieties. Additionally, they have reservations about incorporating these non-native varieties into ELT classrooms. $\mathrm{M}=2.94$ is the corresponding mean value that demonstrates this conclusion.

The second factor in the same questionnaire examined EFL students' perceptions of ELF characteristics. According to the findings derived from this factor, EFL students are more likely to agree on ELF characteristics that facilitate successful exchanges between the speakers. Similarly, they place a lower premium on adhering to native English norms when interacting with others. As a result, the mean value that corresponds to this outcome is $\mathrm{M}=3.90$.

The questionnaire's final factor examined EFL students' perceptions of English language learning objectives. The findings for this factor indicate that EFL students take a neutral stance toward ELF-related English learning objectives, placing a higher premium on attaining a level that enables communication with people from diverse lingua cultural backgrounds than on setting an implausible goal such as achieving native-like English proficiency. To this end, $M=2.72$ is the mean value.

The third research question sought data on EFL students' overall attitudes toward the pedagogical implications of ELF. Descriptive statistics were used to generate a response to the pertinent inquiry by applying them to the quantitative data. Therefore, Table 3 depicts the ultimate indicators from this vantage point. 
Table 3

Overall Perceptions of EFL Students towards the Pedagogical Implications of ELF

\begin{tabular}{lccccccc}
\hline & & Range Value & N & Mean & SD & Min. & Max. \\
\hline Strongly Disagree & $(1)$ & $1.00-1.80$ & & & & & \\
Disagree & $(2)$ & $1.81-2.60$ & & & & & \\
Neutral & $(3)$ & $2.61-3.40$ & 570 & 2.96 & 0.49 & 1.15 & 4.38 \\
Agree & $(4)$ & $3.41-4.20$ & & & & & \\
Strongly Agree & $(5)$ & $4.21-5.00$ & & & & & \\
\hline
\end{tabular}

As shown in Table 3, the lowest score for EFL students' perceptions of the pedagogical implications of ELF is 1.15, while the highest score is 4.38 with a standard error of 0.49 . Despite the deviations, a greater proportion of EFL students, with a mean value of 2.96, choose a neutral attitude toward the pedagogical implications of ELF. Furthermore, the percentage distributions of the overall results are as follows: 15.07 percent strongly disagree, 20.02 percent strongly disagree, 28.22 percent neutral, 23.37 percent agree, and 13.33 percent strongly agree. Additionally, the standard deviation score (0.49) reflects the group's homogeneity by indicating that more than half of the students share a common perception.

The fourth research question sought to build on the third by examining students' perceptions of the pedagogical implications of ELF in relation to four sub-dimensions: English teachers, target language culture, global cultures, and English exams. In that sense, Table 4 summarizes the overall perceptions of EFL students.

Table 4

Factors about the Perceptions of EFL Students towards the Pedagogical Implications of ELF

\begin{tabular}{llll}
\hline Factors & $\mathrm{N}$ & Mean & SD \\
\hline English Teachers & 570 & 2.73 & 0.81 \\
$\begin{array}{l}\text { Target Language } \\
\text { Culture }\end{array}$ & 570 & 3.39 & 1.00 \\
Global Cultures & 570 & & \\
English Exams & 570 & 3.20 & 1.04 \\
\hline
\end{tabular}


The first factor in determining the ELF questionnaire's pedagogical implications was EFL students' perceptions of English teachers. In terms of the outcomes of this factor, EFL students are more ambivalent about whether to prioritize native English speaker teachers over non-natives ones with diverse linguistic and cultural backgrounds. They appear incapable of making a clear choice between the two. In summary, they do not appear to believe that the choice should be limited to one or the other. As a result, the relevant mean value is $\mathrm{M}=2.73$.

The second factor examined EFL students' attitudes toward the target language culture. The results of this factor indicate that EFL students' views on accepting the dominant position of native English culture in ELT classrooms fall into the disagree category. $M=$ 3.39 is the mean value aligned with this effect (reverse coded in favor of ELF).

When it comes to the third factor of this questionnaire, which is about EFL students' perceptions of the involvement of global or international cultures in ELT classrooms, EFL students tend to take a neutral position $(\mathrm{M}=3.20)$ when it comes to including more of an international culture in the teaching and learning of English language. Although they do not wish to limit their learning to only native English cultures, which in this case are represented by either American or British culture, they do not wish to limit their learning to only native English cultures, either.

The final factor of the ELF questionnaire's pedagogical implications examined EFL students' attitudes toward English exams. To this end, the results of this factor indicate that EFL students appear to be neutral $(M=2.91)$ when it comes to acknowledging the need to incorporate international English usage in assessment rather than relying solely on native English norms as a measure of accuracy. Additionally, they are hesitant to include non-native English accents in testing.

\section{RESULTS, DISCUSSIONS AND SUGGESTIONS}

The first section of this research examined how students enrolled in a tertiary level English preparatory program conceptualize ELF. Students generally exhibited a skeptical attitude toward the concept of ELF. To elaborate, data were analyzed in terms of three sub-dimensions: English varieties, ELF characteristics, and English learning objectives.

The first factor in this section sought to elicit information about EFL students' perceptions of the multifaceted nature of English. The findings indicate that students were uncertain about the various global English usages and their anticipated consequences for multinational exchanges. In this regard, they maintain an ambiguous position regarding the necessity of familiarity with non-standard forms of English $(\mathrm{M}=3.00)$. Additionally, they are unsure whether the English language's diversity is a detriment to it $(M=2.95)$. Apart from that, they continue to believe in the superiority of American or British English models $(\mathrm{M}=3.88)$. They believe, however, that English 
should be taught with an awareness of the language's varied uses throughout the world $(\mathrm{M}=3.60)$.

The second factor examined how EFL students perceived ELF features. The findings indicate that EFL students tend to endorse ELF characteristics that emphasize effective communication. In this respect, EFL students frequently place a higher premium on communication than on proper English grammar usage $(M=4.22)$. They believe that grammar errors in speech $(M=4.06)$ or a text written in English $(M=3.60)$ do not constitute a problem as long as intelligibility is not compromised. Similarly, they are unconcerned about their accents being different from those of native speakers as long as they can communicate effectively $(M=4.11)$. Additionally, they advocate for the right of non-native English speakers to pronounce words differently as long as they are comprehensible $(\mathrm{M}=3.52)$.

This section's final factor examined EFL students' perspectives on their English learning objectives. Within this context, EFL students demonstrated perplexing attitudes toward the ultimate goals they intend to accomplish through English learning. On the one hand, they advocate for achieving native-like fluency in English $(M=3.78)$ and believe that they must be as accurate in their English practices as native language speakers $(M=3.75)$. They are, however, unbiased when it comes to the belief that one should strive for a native-like English accent $(M=2.96)$. Additionally, they are ambivalent toward the notion that one should seek familiarity with English accents other than British and American $(\mathrm{M}=3.39)$.

On that note, it appears as though students' perceptions of English are heavily influenced by the ELT market's native-oriented conceptualization of the language, which falls short of meeting the constantly changing needs of its global learners. In a similar vein, Kontra and Csizer (2011) observed that EFL students face a dilemma when deciding whether to pursue English as a native language (ENL) or English as a lingua franca (ELF). On the one hand, students prioritize communication efficiency over proper English usage in light of the language's global status; on the other hand, they advocate for native English proficiency in order to facilitate mutual intelligibility even among interlocutors who speak diverse first languages. In other words, EFL students appear to believe that mastering native English norms will satisfy all of their communication needs with people from diverse linguacultural backgrounds.

Similarly, Murata and Jenkins (2009) argue that students' opposing attitudes toward ELF result in a push-pull effect between ENL and ELF practices at the grass roots level. Jenkins (2007) characterized this ambivalence toward ELF as an unbalanced attitude toward ELF for the same reason. Her research revealed that while students attempted to achieve an English accent that was similar to that of a native speaker, they were also concerned with preserving their own identities and accents that were influenced by their mother tongue. 
Despite these advancements in the English language as a global medium of communication, perceptions based on native language continue to dominate (Cogo, 2010). Holliday (2005) and Jenkins (2007) identify entrenched native speaker ideology as the driving force behind the glorification of native speaker English by policymakers, examination panels, and publishing houses. Additionally, the influence of native-speaker ideology does not appear to diminish quickly as long as the ELT industry overvalues concepts such as norms, cultures, and teachers associated with native English. Additionally, it appears that in order to effect significant change in favor of ELF, it is necessary to raise the awareness of all stakeholders in ELT pedagogy by informing them of English's contemporary engagement as a vehicular language. This is because a genuine transformation is inconceivable without their approval.

This study's second section examined EFL students' perceptions of the pedagogical implications of ELF. Similarly, students' overall perspectives on this subject were ambiguous. In other words, EFL students did not vote for recommendations regarding English language teaching that aligned with the ELF perspective. They were also not directly contradicting them. Four sub-dimensions were examined in greater detail within this context: English teachers, target language culture, global cultures, and English examinations.

This section's first factor investigated EFL students' attitudes toward English teachers (native and non-native). Students do not appear to have a clear preference for a particular type of teacher. In that regard, they disagree with the notion that English textbooks used in Turkey should be written by Turkish English teachers $(M=2.45)$, indicating that they do not place a premium on Turkish English teachers in this regard. Similarly, they are undecided about whether they prefer teachers from native Englishspeaking countries $(M=3.24)$ or whether native English-speaking teachers can help them learn English more effectively ( $M=3.37)$. Additionally, they are unsure about the greater efficiency of non-native English teachers $(\mathrm{M}=2.89)$ or giving them more credit for their teaching abilities (M=2.93).

The second factor sought to elicit information about EFL students' attitudes toward target language culture (Anglo-Saxon). Students do not appear to believe in the necessity of incorporating this culture into English language classes $(M=2.18)$. In other words, they oppose the exclusivity of their classes to American and British life styles. They are, however, impartial regarding the belief that greater awareness of the target language's culture results in increased success with English learning $(\mathrm{M}=3.02)$. To put it succinctly, students do not accept the primacy of Anglo-Saxon culture over other world cultures, but they are undecided about whether knowledge of this culture will facilitate them in learning English more effectively.

The third factor examined EFL students' perceptions of international cultures. In relation to that, EFL students have a tendency to be apathetic toward the notion that international cultures from diverse parts of the world must be incorporated into English instruction $(\mathrm{M}=3.39)$. This could be because they are unsure whether dealing with 
international cultures will benefit their endeavor to learn English. In a similar vein, they face a conundrum regarding the necessity of thorough knowledge of international cultures in order to properly learn and use English $(M=3.01)$. This demonstrates that they are unaware of the implications of dealing with a globally recognized language and the cultural components that it should include.

The final factor aimed to elicit observations from EFL students about English exams. In light of this, they are generally unbiased when it comes to emphasizing international English usage in tests rather than focusing exclusively on native English standards. $(M=3.31)$. Similarly, they maintain a neutral stance toward the requirement that textbooks include a country-specific English, such as American or British, in their presentations $(M=3.34)$. Likewise, they are ambivalent about the requirement that only these two varieties of English be tested in exams ( $M=3.09)$. They are, however, similarly indecisive when it comes to including international accents in English exams $(\mathrm{M}=2.78)$.

In contrast to previous research (Tran, 2000; Pham, 2001; Phan, 2008; Nguyen, 2012; Cunnigham, 2009; Ton \& Pham, 2010; Ngo, 2013), in which participants favored native English as a pedagogical model, participants in this study neither approved nor opposed the instructional implications of ELF. Within this context, one can assert that students do not inevitably choose EFL pedagogy; however, they also do not know what might be an alternative. To maximize the benefits of incorporating an ELF perspective into English instruction, students, as the primary agents of change in education, should be informed about the language's global status. As a result, this is likely to provide them with an opportunity to make informed choices about their preferred model of English in the English classroom.

To conclude, given EFL students' ambivalent attitudes, certain aspects of traditional ELT practices should be reconsidered. One critical aspect that requires reconsideration in this regard is the native English-centric approach to testing. On that note, Cogo, (2009), Jenkins, (2000), and Kubota, (2016) argue that when designing assessment tasks, performative tasks such as accommodation strategies and communication skills focused on various linguistic competences should be considered. Additionally, it is critical to overcome native English's privileged position and challenge its superiority in a variety of international tests in order to avoid making native standards the primary criterion for evaluating students' English proficiency. Overall, if the ELF perspective is realized, it may eventually enable students to develop the necessary accommodation strategies and communication skills to deal with the diverse contexts of international communication.

Another critical aspect that requires reconsideration is EFL teachers' perspectives on the English model that students should be provided with. Since teachers, along with students, are considered major agents of change, their insufficient understanding of the emerging realities of this language may result in their continued promotion of native English norms in ELT classrooms. Updating teachers' English knowledge entails increasing their awareness of the language's current sociolinguistic reality and its implications for the classroom (Dewey, 2015; Widdowson, 2015; İnal \& Özdemir, 2015; 
Seidlhofer, 2011). English teachers who are aware of ELF are more likely to make sound pedagogical choices regarding classroom practices. As a result, they can also contribute to students' understanding of English as a global medium of communication.

Finally, the culture provided in English classes should be reassessed. As long as the associated teaching materials place a premium on native English-oriented culture, students are likely to continue to struggle with the dichotomy between English for international use and English with native norm-focused characteristics. For the time being, instructional materials do not appear to adequately prepare students for international communication in English. However, teachers who have received adequate training can adapt these materials for use in an ELF context. Bayyurt and Sifakis (2015) argue that once English teachers are sufficiently informed about ELF, they are more likely to endorse recent developments in English and their pedagogical implications.

The following suggestions can be made to ELT stakeholders in light of the findings of this study in order to improve traditional English language education that lacks a global perspective on ELT and to increase EFL students' understanding of contemporary sociolinguistic realities of English:

1. Students' understanding of English as a global lingua franca should be increased, as should their ability to make educated linguistic choices in this regard.

2. It is critical to overcome native English's privileged position and to contest its superiority in English assessments so that native standards are not used as the major criterion for evaluating students' English skills.

3. English teachers who are cognizant of ELF should make required pedagogical decisions in their classroom practices to aid students' comprehension of English as a global lingua franca.

4. The culture provided in the English classroom should represent the international nature of English, rather than focusing exclusively on native English culture, in order to increase EFL students' knowledge of the language's current sociolinguistic realities.

Concerning the study's limitations, participants were recruited from a university, however in another study, participants might be recruited from a variety of educational contexts. Furthermore, while this study only collected quantitative data, other studies may employ a variety of data collection instruments. Finally, despite the fact that the study's population was solely made up of Turkish students, other research can include participants of various nationalities.

Future directions may include doing a comparable study in a variety of different settings, including university departments where English is the primary medium of teaching or a high school. Additionally, the study can be done with a bigger sample size within a similar educational context. Moreover, additional ELT stakeholders could be included in 
a subsequent study. Finally, the same research can be carried out with the addition of interviews as a data collection instrument.

\section{References}

Brumfit, C. J. (2001). Individual freedom in language teaching: Helping learners to develop a dialect of their own. Oxford University Press.

Bruthiaux, P. (2003). Squaring the circles: Issues in modeling English worldwide. International Journal of Applied Linguistics, 13(2), 159-178. https://doi.org/10.1111/1473-4192.00042

Bayyurt, Y., \& Sifakis, N. C. (2015). Developing an ELF-aware pedagogy: Insights from a self-education programme. In Vettorel, P (Ed.), New frontiers in teaching and learning English (pp. 55-76). Cambridge Scholars Publishing.

Bayyurt, Y. (2008). A lingua franca or an international language: The status of English in Turkey [Paper presentation]. ELF Forum, Helsinki, Finland.

Bayyurt, Y., \& Sifakis, N. C. (2015). ELF-aware in-service teacher education: A transformative perspective. In H. Bowles, \& A. Cogo (Eds.), International Perspectives on English as a Lingua Franca (pp. 117-135). Basingstoke, UK: Palgrave Macmillan.

Babbie, E. R. (2010). The practice of social research (12th ed.). Wadsworth.

Coşkun, A. (2011). Future English teachers' attitudes towards EIL pronunciation. Journal of English as an International Language, 6(2), 46-68.

Canagarajah, S. A. (2006) Negotiating the local in English as a lingua franca. Annual Review of Applied Linguistics, 26, 197-218. https://doi.org/10.1017/S0267190506000109

Cogo, A. (2010). Strategic use and perceptions of English as a lingua franca. Poznań Studies in Contemporary Linguistics, 46(3), 295-312. https://doi.org/10.2478/v10010-010-0013-7

Cunningham, U. (2009). Models and targets for English pronunciation in Vietnam and Sweden. Research in Language, 7, 113-128. https://doi.org/10.2478/v10015-0090008-3

Cogo, A. (2009). Accommodating difference in ELF conversations: A study of pragmatic strategies. In A. Mauranen \& E. Ranta (Eds.). English as a Lingua Franca: Studies and findings (pp. 254-273). Cambridge Scholars Publishing.

Deniz, E. B., Özkan, Y., \& Bayyurt, Y. (2016). English as a lingua franca: Reflections on ELF-related issues by pre-service English language teachers in turkey. The Reading Matrix: An International Online Journal, 16(2), 144-161.

Dewey, M. (2015). ELF, teacher knowledge and professional development. In H. Bowles \& A. Cogo (Eds.), International perspectives on English as a Lingua Franca. Pedagogical insights (pp. 176-193). Palgrave Macmillan.

Dörnyei, Z. (2007). Research methods in applied linguistics. Oxford University Press. 
Griffiths, C., \& Soruç, A. (2019) Contextual differences regarding students' perceptions of English as a lingua franca according to subject major and nationality. The Journal of Language Learning and Teaching, 9(1), 53-69.

George, D., \& Mallery, P. (2003). Using SPSS for Windows step by step: A simple guide and reference (4th ed.). Pearson Education.

Geçkinli, F. (2020). English as a lingua franca: Turkish EFL teachers' and students' perceptions. Unpublished doctoral dissertation. Çanakkale, Turkey.

Holliday, A. (2005). The struggle to teach English as an international language. Oxford University Press.

Hemmati, F., \& Mojarrad, H. (2016). E-learning and distance education: A study of Iranian teaching English as a Foreign Language Masters Students. Malaysian Journal of Distance Education, 18(1), 53-70. https://doi.org/10.21315/mjde2016.18.1.4

İnceçay, G., \& Akyel, A. S. (2014). Turkish EFL teachers' perceptions of English as a lingua franca. Turkish Online Journal of Qualitative Inquiry, 5(1), 1-12.

İnal D., \& Özdemir E. (2015). Re/considering the English language teacher education programs in Turkey from an ELF standpoint: what do the academia, pre-service and in-service teachers think? In Bayyurt Y., Akcan S. (Eds.), Current perspectives on pedagogy for English as a Lingua Franca (pp. 135-152). De Gruyter Mouton.

Jenkins, J. (2012). English as a Lingua Franca from the classroom to the classroom. ELT Journal, 66(4), 486-494.

Jenkins, J. (2007). English as a lingua franca: Attitude and identity. Oxford University Press.

Jenkins, J. (2006). Current perspectives on teaching world Englishes and English as a lingua franca. Tesol Quarterly, 40(1), 157-181.

Jenkins, J. (2015). Repositioning English and multilingualism in English as a Lingua Franca. Englishes in Practice, 2(3), 49-85. https://doi.org/10.1515/eip-2015-0003

Jenkins, J. (2003). World Englishes. Routledge.

Jenkins, J. (2000). The phonology of English as an international language. Oxford University Press.

Kachru, B. (1985). Standards, codification and sociolinguistic realism: The English language in the outer circle. In R. Quirk \& H. G. Widdowson (Eds.), English in the World: Teaching and Learning the Language and Literatures (pp. 11-30). Cambridge University Press.

Kontra, E., \& Csizer, K. (2011). They can achieve their aims without native skills in the field of work or studies: Hungarian students' views on English as a lingua franca. Studies in Second Language Learning and Teaching, 1(1), 135-152. https://doi.org/10.14746/ssllt.2011.1.1.8

Kubota, R. (2016). The multi/plural turn, postcolonial theory, and neoliberal multiculturalism: Complicities and implications for applied linguistics. Applied Linguistics, 37(4), 474-494. https://doi.org/10.1093/applin/amu045

Levin, T., \& Wadmany, R. (2006). Teachers' beliefs and practices in technology-based classrooms: A developmental view. Journal of Research on Technology in Education, 39(2), 157-181. https://doi.org/10.1080/15391523.2006.10782478

Murata, M., \& Jenkins, J. (2009). Global Englishes in Asian Contexts: Current and Future Debates. Palgrave Macmillan. 
Ferguson, G. (2013). Exploring ELF: Academic English shaped by Non-native Speakers Anna Mauranen. TESOL Quarterly, 47(2), 431-433. https://doi.org/10.1002/tesq.88

Mackey, A., \& Gass, S. M. (2005). Second language research: Methodology and design. Lawrence Erlbaum Associates.

Nguyen, Q. T. (2012). Awareness of world Englishes of Vietnamese users of English. Tap San Khoa hoc Xa Hoi va Nhan Van, 69-78.

Ngo, L. H. P. (2013). An investigation into Vietnamese teachers' and students' perception of English as a lingua franca. [Unpublished master's thesis]. University of Southampton.

Pung, C. S. (2009). Beyond the Three Circles: A New Model for World Englishes. [Unpublished master's thesis]. National University of Singapore.

Peterson, R. A. (2000). A Meta-Analysis of Variance Accounted for and Factor Loadings in Exploratory Factor Analysis. Marketing Letters, 11(3), 261-275. https://doi.org/10.1023/A:1008191211004

Pan, L., \& Block, D. (2011). English as a "global language" in China: An investigation into learners' and teachers' language beliefs. System, 39(3), 391-402. https://doi.org/10.1016/j.system.2011.07.011

Pham, H. H. (2001). Teacher development: A real need for English Departments in Vietnam. English Teaching Forum, 39(4), 30-33.

Phan, L. H. (2008). Teaching English as an International Language: Identity, resistance and negotiation. Multilingual Matters.

Pinsonneault, A., \& Kraemer, K. (1993). Survey research methodology in management information systems: An assessment. Journal of Management Information Systems, 10(2), 75-105. https://doi.org/10.1080/07421222.1993.11518001

Ranta, E. (2010). English in the real world vs. English at school: Finnish English teachers' and students' views. International Journal of Applied Linguistics, 20(2), 156-177. https://doi.org/10.1111/j.1473-4192.2009.00235.x

Soruç, A. (2015). Non-native Teachers' Attitudes towards English as a Lingua Franca. Hacettepe University Journal of Education, 30(1), 239-251.

Soruç, A. (2020). English as a Lingua Franca and Good Language Teachers. In C. Griffiths \& Z. Tajeddin (Eds.), Lessons from Good Language Teachers (pp. 67-79). Cambridge University Press.

Soruç, A., \& Griffiths, C. (2021). Inspiring Pre-service English Language Teachers to Become ELF aware. RELC 1-13. https://doi.org/10.1177/00336882211001966

Seidlhofer, B. (2004). Research perspectives on teaching English as a Lingua Franca. Annual Review of Applied Linguistics, 24(1), 209-239. https://doi.org/10.1017/S0267190504000145

Seidlhofer, B. (2011). Understanding English as a lingua franca. Oxford University Press.

Sifakis, N. (2019) ELF awareness in English language teaching: Principles and processes. Applied Linguistics 40(2), 288-306.

Sifakis, N. (2009). Challenges in teaching ELF in the periphery: the Greek context. ELT Journal, 63(3) 230-237.

Timmis, I. (2002). Native-speaker norms and International English: a classroom view. ELT Journal, 56(3), 240-249. https://doi.org/10.1093/elt/56.3.240 
Tran, T. L. (2000). A Vietnamese perspective on World Englishes. Teachers' Edition, 4, 26-32.

Ton, N. N. H., \& Pham, H. H. (2010). Vietnamese teachers' and students' perceptions of global English. Language Education in Asia, 1(1), 48-61.

Widdowson, H. G. (2015). ELF and teaching: Principles and practice [Paper presentation]. 8th English as a Lingua Franca Conference. Beijing International Convention Center, Beijing, China.

Wang, D. (2013). The use of English as a lingua franca in teaching Chinese as a foreign language: A case study of native Chinese teachers in Beijing. In H. Haberland, D. Lønsmann \& B. Preisler (Eds.), Language alternation, language choice and language encounter in international tertiary education (pp. 161-177). Springer.

Widdowson, H. (2015). ELF and the pragmatics of language variation. Journal of English as a Lingua Franca, 4(2), 359-372. https://doi.org/10.1515/jelf-2015-0027

Yoneoka, J. (2002). Englishes in Asia. The Linguistics Journal, 1-24.

Zabitgil Gülseren, Ö., \& Sarıca, T. (2020). Native Language Inclination of Students and Teachers at a Public Secondary School: Native Language (Turkish) Usage in English Language Lessons. In. V. Krystev, M. S. Dinu, R. Efe, \& E. Atasoy (Eds). Advances in Social Science Research (pp.181-203). St. Kliment Ohridski University Press. http://doi.org/10.5281/zenodo.4603614 
Ethics approval was obtained from the Ethics Committee of İstanbul Sabahattin Zaim University with the decision dated 28.01.2021 numbered 2021/01.

\section{Statement of Contribution of Researchers to the Article:}

1st author contribution rate: $50 \%$

2nd author contribution rate: $50 \%$

\section{Conflict of Interest Statement:}

There is no conflict of interest.

Statement of Financial Support or Acknowledgment:

No financial support was received from any institution for this study. 